\title{
Regarding the informed consent and its documentation
}

\author{
Aldo Barajas-Ochoa1* and Zalathiel Barajas-Ochoa² \\ ${ }^{1}$ Department of Medicine, Rutgers New Jersey Medical School, New Jersey, United States; ${ }^{2}$ Instituto Mexicano del Seguro Social, Specialty Hospital \\ 25, Monterrey, Nuevo León, Mexico
}

We read with interest the article "Informed consent: recommendations for its documentation" written by Celis et al.," published in Gaceta Médica de México 2018 number 6 .

The article adequately points out that the informed consent (IC) is an act of equality that goes beyond the declaration of risks and benefits. We consider it important to insist on the fundamental difference between the IC and the informed consent document (ICD). The IC is a complex process that requires five elements: decision-making capacity, explanation of the proposed intervention, understanding, willingness and authorization. ${ }^{2,3}$ First, the patient (or his/her representative) must have decision-making capacity. Then, the doctor (ideally, the physician who will perform the intervention or a physician deeply knowledgeable of the intervention) should ensure that the patient understands the diagnosis and prognosis of the disease and explain, in an understandable manner, the nature and purpose of the proposed intervention, the risks and benefits, and available alternatives. ${ }^{4}$ Finally, the patient decides without coercion and accepts the intervention or not. The IC is a communication process ${ }^{3}$ while ICD is only a way of documenting patient's authorization..$^{2-4}$ The fact that a patient signs an ICD does not imply the existence of an IC. ${ }^{4}$

In addition, the article states that the purpose of the ICD is not to protect the doctor (this distorted use is well documented ${ }^{4,5}$ ), "but to protect patients against eventual abuses and omissions by health personnel". It is alarming to think of those "abuses" to the patient, which make us question the suitability for being health personnel of those who deliberately violate the principles of beneficence and non-maleficence.

\section{References}

1. Celis MÁ, Halabe J, Arrieta O, Burgos R, Campillo C, De la Llata M, et al. El consentimiento informado: recomendaciones para su documentación. Gac Med Mex. 2018;154:716-718. DOI: 10.24875/GMM.18004339.

2. De la Mora-Molina H, Barajas-Ochoa A, Sandoval-García L, Navarrete-Lorenzon M, Castañeda-Barragán EA, Castillo-Ortiz JD, et al. Trends of informed consent forms for industry-sponsored clinical trials in rheumatology over a 17-year period: Readability, and assessment of patients' health literacy and perceptions. Semin Arthritis Rheum. 2018;48:547552. DOI: 10.1016/j.semarthrit.2018.03.008.

3. Grady C. Enduring and emerging challenges of informed consent. N Engl J Med. 2015;372:855-862. DOI: 10.1056/NEJMra1411250.

4. Jefford M, Moore R. Improvement of informed consent and the quality of consent documents. Lancet Oncol. 2008;9:485-493. DOI: 10.1016/S14702045(08)70128-1.

5. Faden R, Beauchamp T. A history and theory of informed consent. Nueva York, EE. UU.: Oxford University Press; 1986.
Gac Med Mex. 2019;155:201-201

Contents available at PubMed www.gacetamedicademexico.com 